\title{
The Examination of the laboratory anxiety, state and trait anxiety of university students in high voltage laboratory
}

\author{
İbrahim Güneş ${ }^{1}$ \\ Zeliha Özsoy Güneş ${ }^{2}$
}

\begin{abstract}
With this study were aimed the investigation of the state and trait anxiety levels of ElectricElectronic Engineering students on High Voltage Laboratory anxiety. This research is designed as relational scanning model. The samples of the study comprised 113 students from ElectricElectronic Engineering in Engineering Faculty. In the study; "High Voltage Laboratory Anxiety Scale" with three factors which was developed by Güneş and Özsoy-Güneş (2015) and "The State and Trait Anxiety Scale" was developed by Spielberger and his colleagues (1970), adapted to Turkish by Öner and Le Compte (1985) are used as tool of data collection. In order to analyze the data, SPSS 20.00, Pearson correlation coefficient techniques and regression analysis techniques are used. At the end of the study, between all scales has a positive relation. Multiple linear regression analysis showed that the trait anxiety and laboratory anxiety of students has been found to be effective on the state anxiety of students.
\end{abstract}

Keywords: Laboratory Anxiety; State Anxiety; Trait Anxiety; Regression Analysis.

\section{Introduction}

Laboratories are active learning environments where knowledge is formed with generalization. These environments enable us to gain designation, production, analyzing and testing skills and to solve the problems encountered. Emotional and social factors are affective as much as cognitive factors in learning. The most important factors among the affective determinants influencing student success in laboratory are attitude and anxiety. High level of anxiety result in disturbance of the individual, problem with focusing and less permanence of the acquired information.

Anxiety can be defined as a feeling of fear without knowing the source of the problem, and is regarded as an undesired emotional condition both in children and adults (Duman, 2008). Anxiety can be studied from two different points of view; feelings that depend on temporary situations and ongoing feelings that have been developed over time. Studies on this subject have proven that ongoing anxiety that was developed in the past, affects success negatively, however anxiety that depend on temporary situations affects success positively. Both successful and less successful students were found to have been anxious about not learning the subjects, however successful students were found to have suffer anxiety more about not learning the subject than failing in the exam. Students who failed, had more anxiety about failing the exam than learning the subject itself (Laukenmann, Bleicher, Fuß, Gläser-Zikuda, Mayring, Von Rhönec, 2003).

In high levels of anxiety, an individual loses its capability of abstract thinking, mental flexibility and fluidity. On the other hand, lack of anxiety may affect learning negatively as well (Baymur, 1994). So

\footnotetext{
1 Assist. Prof. Dr., Istanbul University, Faculty of Engineering, gunesi@istanbul.edu.tr.

2 Assist. Prof. Dr., Istanbul University, Faculty of Hasan Ali Yücel Education, ozsoyz@istanbul.edu.tr.
} 
Güneş, İ., \& Özsoy Güneş, İ. (2016). The Examination of the laboratory anxiety, state and trait anxiety of university students in high voltage laboratory. Journal of Human Sciences, 13(2), 3439-3445. doi:10.14687/jhs.v13i2.3922

besides high level of anxiety, lack of anxiety can be regarded as a negative effect on an individual's academic performance (Okur \& Bahar, 2010).

Laboratory learning includes affective factors like attitude, interest, anxiety besides cognitive and psychomotor factors (Yeşilkayal1, 1996; Demirbaş \& Yağbasan, 2004). The most important factors among the affective determinants influencing student success in laboratory are attitude and anxiety. The study shows that the students with the higher anxiety have lower success.

The higher the level of anxiety in any subject is, the less successful the individual is at that subject. For all students who study at vocational schools, to be brought up as healthy, knowledgeable, and successful individuals, the anxieties regarding their occupations must be defined and the negativities must be minimized (Geoffrey \& Behets, 1999).

State anxiety is the subjective fear experienced by the individual due to a stressful situation the individual is in. When stress is great, state anxiety level increases, however, when stress is abolished it decreases (Öner \& Le Compte, 1998). State anxiety shows the emergent situation that is characterized by distress, worry and tension (Konter, 1996). In short, state anxiety is the expression of complex emotive reactions shown by the individual due to stress caused by external conditions, or by threatening situations (Jones, 1995).

Trait anxiety means an individual's proneness to experiencing anxiety. In other words, the tendency of the individual to perceive or interpret situations as generally stressful. It's the discontent and unhappiness feelings as a result of perceiving neutral situations by objective standards as dangerous and threatening to his/her self (Öner \& Le Compte 1998). Meanwhile, it is indicated that individuals with high trait anxiety levels show anxiety symptoms quicker and more often in other situations such as (before or after an exam) (Öner \& Le Compte, 1998).

As understood from these definitions, an individual is consciously aware of the anxiety feelings. In relation to particular situations in trait anxiety, the individual has a general and objective tendency. (Konter, 1996). As opposed to state anxiety, trait anxiety is a part of the character.

\section{Objective of the Research and Sub Problems}

With this study were aimed the investigation of the state and trait anxiety levels of ElectricElectronic Engineering students on High Voltage Laboratory anxiety.

1. What are the anxiety levels of students towards High Voltage Laboratory?

2. What are the state and trait anxiety levels of students?

3. Is there a connection between the state and trait anxiety levels and the anxiety levels of students towards High Voltage Laboratory?

4. Are there the effects of the anxiety levels of students towards High Voltage Laboratory and the trait anxiety levels over the state anxiety levels of students?

\section{Method}

In this study, quantitative research method and relational screening model has been used.

Model of the Research: Research model is relational screening. In this relational screening model in order to reach certain aims, the relation between special events are tried to be explained and the existence or the level of covariance between two or more variances are tried to be determined (Cohen, Manion and Morrison, 2000; Karasar, 2008).

Sample of the Research: The sample of this study is formed by $15(13,3 \%)$ female and $98(86,7 \%)$ male, a total of 113 senior students who have taken high voltage laboratory course of ElectricElectronic Engineering. The age range is between 20-27. 
Güneş, İ., \& Özsoy Güneş, İ. (2016). The Examination of the laboratory anxiety, state and trait anxiety of university students in high voltage laboratory. Journal of Human Sciences, 13(2), 3439-3445. doi:10.14687/jhs.v13i2.3922

\section{Data Collection Instruments}

For research a two fold form has been created. In the first part, "High Voltage Laboratory Anxiety Scale" developed by Güneş \& Özsoy-Güneş (2015) was applied to the students in the survey to determine the anxiety levels. Second part includes "The State and Trait Anxiety Scale" was developed by Spielberger and his colleagues (1970), adapted to Turkish by Öner and Le Compte (1998) are used as tool of data collection.

In the study; "High Voltage Laboratory Anxiety Scale" developed by Güneş \& Özsoy-Güneş (2015) in order to measure the anxiety levels of students towards High Voltage Laboratory was used as the data collection tool. The scale is five-point Likert type. The Located 14 items in the scale are consisted from expressions supporting anxiety. The response range of the scale is from: "definitely disagree" (1); "disagree" (2); "uncertain" (3); "agree" (4); "completely agree" (5). High scores from factors of scale are indicating high anxiety and low scores are for low anxiety. The scale consists 3 factors. These factors are defined as; 1 . Work and use of materials in the laboratory, 2. Collaboration and data recording, 3. Time management. The first factor is made up of 6 items $(1,4,5,8,12,17)$, the second factor of $5(2,6,9,10,14)$ and the third of $3(3,7,11)$. Cr $\alpha$ reliability for the whole of the scale was found 0,887 , related to first, second and third factors as $0,852,0,856$ and 0,698 . The minimum and the maximum score that can be taken; from the total scale are between 14-70 points. After dividing the number of questions, the factor scores were multiplied by 10 . In this way, the lowest value 10 , and the highest value 50 standard scores are obtained.

State - Trait Anxiety Inventory (STAI) was developed by Spielberger, Gorsuch and Lushene in 1970 in order to determine state and trait anxiety levels separately. The validity and reliability of this inventory were proven by Öner ve Le Compte (1985). State-Trait Anxiety Inventory is a selfevaluation survey made up of short statements. Ten years of testing has led phycologists to the conclusion that the inventory can be applied to both the young and the adult (Öner \& Le Compte, 1998). The scale is a likert type assessment tool made up of 20 questions to evaluate state and trait anxiety levels separately. High scores indicate high anxiety levels while low scores indicate low anxiety levels. The scores derived from both scales range 20-80. It is a four points scale ranging from "Never" to "Completely". There are two statements in State-Trait Anxiety Inventories. Direct statement express negative emotions, reverse statements express positive emotions. In State Anxiety Scale (STAI-S), the reverse statements are the $1^{\text {st }}, 2^{\text {nd }}, 5^{\text {th }}, 8^{\text {th }}, 10^{\text {th }}, 11^{\text {th }}, 15^{\text {th }}, 16^{\text {th }}, 19^{\text {th }}$ and $20^{\text {th }}$ items. In Trait Anxiety Scale (STAI-T) the reverse statements are $21^{\text {st }}, 26^{\text {th }}, 27^{\text {th }}, 30^{\text {th }}, 33^{\text {th }}, 36^{\text {th }}$, $39^{\text {th }}$. In direct statements 4 points value answers, in reverse statements 1 point value answers show that anxiety level is high. State Anxiety Scale (STAI-S) is a highly sensitive tool in evaluating emotional reactions changing abruptly. Trait Anxiety Scale (STAI-T) in the second part of the inventory made up of 20 items, aims at evaluating the consistency of anxiety the individual tends to experience (Özyurt, 2013).

\section{Evaluation of the Data}

In this research, whether the data obtained displays normal distribution or not is understood by looking at Kolmogrow-Simirnov and Shapiro Wilk tests. When the number of data is less than 29, Shapiro Wilk test is used and when the number of data is over 29 or larger, Kolmogrow-Simirnov (Lilliefors) test is used (Kalayc1, 2010). In order to determine whether the data displays normal distribution or not, "One Group Kolmogorov-Smirnov Test" test has been applied to the data collected by the scale. The values attained are; the "High Voltage Laboratory Anxiety (HVLA) Scale" $(Z=0,969, p>, 05)$, the state anxiety scale $(Z=0,797, p>, 05)$, the trait anxiety scale $(Z=0,948$, $\mathrm{p}>, 05)$. All collected data have normal distribution with regards to all variables.

In order to analyze the data, SPSS 20.00, Pearson correlation coefficient techniques and regression analysis techniques are used. In all statistical processes significance at a level of , 05 has been seeked. 
Güneş, İ., \& Özsoy Güneş, İ. (2016). The Examination of the laboratory anxiety, state and trait anxiety of university students in high voltage laboratory. Journal of Human Sciences, 13(2), 3439-3445. doi:10.14687/jhs.v13i2.3922

\section{Findings}

The research findings are evaluated in the context of problems.

Problem 1. What are the anxiety levels of students towards High Voltage Laboratory?

The sample of this study is formed by 113 students from Electric- Electronic Engineering. The minimum and the maximum score that can be taken; from the total scale are between 14-70 points, from all factors are between 10-50. In this study, the taken total scale score was calculated as 27,0531. When scale factors are evaluated, it was found that students scored the highest in "Work and use of materials in the laboratory" factor, also they scored lowest in "Collaboration and data recording" (Table 1).

Table 1. The anxiety levels of students towards High Voltage Laboratory

\begin{tabular}{llccc}
\hline HVLA Scale and Factors & $\mathbf{X}$ & SD & SE \\
\hline \multirow{3}{*}{ Factors } & Work and use of materials in the laboratory & 21,4749 & 7,62707 &, 71749 \\
\cline { 2 - 5 } & Collaboration and data recording & 17,2035 & 6,80094 &, 63978 \\
\cline { 2 - 5 } & Time management & 18,5546 & 7,24947 &, 68197 \\
\hline HVLA Scale Total Score & 27,0531 & 8,46088 &, 79593 \\
\hline
\end{tabular}

Problem 2. What are the state and trait anxiety levels of students?

The minimum and the maximum score that can be taken from the scales are between 20-80. In this study, the taken the state anxiety scale score as 40,1150, the taken the trait anxiety levels scale score as 42,0177 were calculated (Table 2).

Table 2. The state and trait anxiety levels of students towards High Voltage Laboratory

\begin{tabular}{lccc}
\hline Scales & $\mathbf{X}$ & SD & SE \\
\hline The Trait anxiety & 40,1150 & 10,58111 &, 99539 \\
\hline The State anxiety & 42,0177 & 6,91786 &, 65078 \\
\hline
\end{tabular}

Problem 3. Is there a connection between the state and trait anxiety levels and the anxiety levels of students towards High Voltage Laboratory?

As a result of Pearson Multiplication Momentum Correlation Analysis, conducted to define the relations between the high voltage laboratory anxiety scale and factors and the state and trait anxiety levels scales; the high voltage laboratory anxiety scale total score and the state and trait anxiety scales have a significant positive relation $(\mathrm{p}<, 01)$ (Table 3$)$.

Table 3. Pearson Multiplication Momentum Correlation Analysis Results conducted to define relations of the scales and factors.

\begin{tabular}{|c|c|c|c|c|c|c|}
\hline & \multicolumn{4}{|c|}{ HVLA Scale and Factors } & \multirow[b]{2}{*}{$\begin{array}{l}\text { The trait } \\
\text { anxiety }\end{array}$} & \multirow[b]{2}{*}{$\begin{array}{l}\text { The state } \\
\text { anxiety }\end{array}$} \\
\hline & $\begin{array}{l}\text { Work and use } \\
\text { of materials in } \\
\text { the laboratory }\end{array}$ & $\begin{array}{c}\text { Collaboration } \\
\text { and data } \\
\text { recording }\end{array}$ & $\begin{array}{c}\text { Time } \\
\text { management }\end{array}$ & $\begin{array}{c}\text { HVLA } \\
\text { Scale Total } \\
\text { Score } \\
\end{array}$ & & \\
\hline $\begin{array}{l}\text { The trait } \\
\text { anxiety }\end{array}$ & $r=, 140$ & $\mathrm{r}=, 266(* *)$ & $\mathrm{r}=, 229(*)$ & $\mathrm{r}=, 242(* *)$ & 1 & $\mathrm{r}=, 507(* *)$ \\
\hline $\begin{array}{l}\text { The state } \\
\text { anxiety }\end{array}$ & $\mathrm{r}=, 208(*)$ & $\mathrm{r}=, 159$ & $\mathrm{r}=, 214\left(^{*}\right)$ & $\mathrm{r}=, 231\left(^{*}\right)$ & $\mathrm{r}=, 507(* *)$ & 1 \\
\hline $\begin{array}{c}\text { HVLA } \\
\text { Scale Total } \\
\text { Score } \\
\end{array}$ & $\mathrm{r}=, 894(* *)$ & $\mathrm{r}=, 837(* *)$ & $\mathrm{r}=, 700(* *)$ & 1 & $\mathrm{r}=, 242(* *)$ & $\mathrm{r}=, 231\left(^{*}\right)$ \\
\hline
\end{tabular}

Problem 4. Are there the effects of the anxiety levels of students towards High Voltage Laboratory and the trait anxiety levels over the state anxiety levels of students? 
Güneş, İ., \& Özsoy Güneş, İ. (2016). The Examination of the laboratory anxiety, state and trait anxiety of university students in high voltage laboratory. Journal of Human Sciences, 13(2), 3439-3445. doi:10.14687/jhs.v13i2.3922

The objective here is not to produce an estimation model, but to examine influence of variables on each other, simple linear regression was needed.

Prediction power of each variable with regards to Students' Laboratory anxiety and the trait anxiety on the state anxiety levels was studied. While, we were looking into this question, simple linear regression analyses were done in order to determine whether independent variables predict the state anxiety meaningfully or not and the results were shown in Table 4.

Table 4. Simple Linear Regression Analysis Results relating to predict the state anxiety of laboratory anxiety and the trait anxiety

\begin{tabular}{lccccccc}
\hline Variables & $\mathbf{B}$ & Std Error $_{\mathbf{B}}$ & $\begin{array}{c}\text { Standardized } \\
\text { Coefficients } \boldsymbol{\beta}\end{array}$ & $\mathbf{R}$ & $\mathbf{R}^{2}$ & $\mathbf{t}$ & $\mathbf{F}$ \\
\hline The trait anxiety &, 332 &, 053 &, 507 &, 507 &, 257 & $6,204^{* *}$ & $38,485^{* *}$ \\
\hline HVLA Scale &, 185 &, 074 &, 231 &, 231 &, 053 & $2,625^{* *}$ & $6,258^{* *}$ \\
\hline
\end{tabular}

When Table 4 is analyzed, it is observed that variance analysis results are meaningful at $\left(\mathrm{F}_{\text {Trait }}\right.$ $\left.{ }_{\text {anxiety }}=38,485, \mathrm{~F}_{\text {lab anxiety }}=6,891\right) \mathrm{p}<0,01$ level. The fact that variance analysis results are meaningful shows that there is a linear relation between dependent and independent variables. (Ergün, 1995). In the table it is seen that each variable of Laboratory anxiety and the trait anxiety, predicts the state anxiety positively meaningful $(\mathrm{p}<0,01)$. When the variables are analyzed individually, it is observed that, $26 \%$ of the state anxiety is predicted by the trait anxiety as, $6 \%$ Laboratory anxiety. As explanation coefficient is bigger than $14 \%$, it is possible to say that independent variables have a great effect on dependent variables (Cohen, 1988). When predictive variables coefficients are analyzed, it is observed that the trait anxiety variable has (,507), Laboratory anxiety variable has (,231) regression coefficient.

\section{Results}

Anxiety is a term that refers to feelings such as discomfort, wincing and unrest without a specific reason (Inanç, 1997). Anxiety is a universal feeling and experience students have just as many other people (Aral \& Başar, 1998). There is a close relation between anxiety that affects all vital activities and learning. Even though the quality of this relationship is not known clearly, it is accepted that a certain level of anxiety is necessary for learning (Cüceloğlu, 1996).

Although there are cognitive, affective and kinesthetic dimensions of learning, studies show that learning is generally limited with the cognitive dimension (Mintzes, Wandersee \& Novak, 1998). However, besides social and emotional traits that affect learning, effects of positive and negative attitudes, students' requirements, interests, expectations and motivation shouldn't be disregarded. Among such negative feelings, anxiety plays an important role (Laukenmann et al., 2003).

High voltage issues is a key area for Electric-Electronic Engineering, as it is important for all engineering fields. The awareness of the students while entering to these laboratories and applying the steps accordingly have a crucial part for the safety of many people. At this point; in order to observe if the students' anxiety in this fields; in other words to measure the anxiety levels of the students, considering the level of the anxiety in these high voltage transmission laboratories can have an effect on success.

The minimum and the maximum score that can be taken from the state and trait anxiety scales are between 20-80. In this study, the taken the state anxiety scale score as 40,1150, the taken the trait anxiety levels scale score as 42,0177 were calculated.

The scores that can be taken from high voltage transmission laboratory anxiety scale (HVLA) range from 14 to 70 . In study, the taken total scale score was calculated as 27,0531. Considering this result, it can be suggested that students have low level of anxiety towards laboratory. When scale factors are evaluated, the highest level of anxiety is seen in Work and use of materials in the 
Güneş, İ., \& Özsoy Güneş, İ. (2016). The Examination of the laboratory anxiety, state and trait anxiety of university students in high voltage laboratory. Journal of Human Sciences, 13(2), 3439-3445. doi:10.14687/jhs.v13i2.3922

laboratory factor while the levels are lower in time management, Collaboration and data recording. Erökten (2010) indicated that in the beginning students have anxiety towards the laboratory and as they do experimentations they have less anxiety towards chemical laboratory. It is possible to say that students must spend more time in laboratory environment and must know the equipment used better and have more information about them (Kırbaşlar, Güneş, Deringöl, 2008).

As a result of the analysis conducted in order to determine, to what degree Students' the trait anxiety and laboratory anxiety explain their state anxiety, it was found that the variables explain $\% 27$ of the variance. This shows that students' the trait anxiety and their laboratory anxiety has an impact on their state anxiety. In addition to that, the results show that, the trait anxiety have a higher share in prediction of the state anxiety compared to laboratory anxiety. Research findings have shown that trait anxiety and laboratory anxiety predict undergraduate students' state anxieties meaningfully.

\section{Suggestions}

As in education, emotional and social factors are as important as cognitive ones and because, attitude and anxiety are the most important effective factors that affect student success in laboratory, in order for the students to be successful and in order for the learning to be permanent, anxiety levels need to be not high.

In the study we conducted, the anxiety towards high voltage laboratory was found not too high, while students' state anxiety levels were found to be high. When the cause of this anxiety was searched, the trait anxiety levels were found to be effective substantially.

As more experiments are conducted, students' laboratory anxiety levels are expected to get lower, so it is strongly suggested that importance must be attached to applied classes, especially in vocational education.

The performance of experiments by students in laboratories will aim at gaining skills as well as knowledge and will be effective in lowering their anxieties.

\section{Acknowledgements}

This work was supported by Scientific Research Projects Coordination Unit of Istanbul University. Project number: 20506.

\section{References}

Aral, N., \& Başar, F. (1998). Çocukların Kayg1 Düzeylerinin Yaş, Cinsiyet, Sosyo Ekonomik Düzey ve Ailenin Parçalanma Durumuna Göre İncelenmesi. Ë̆itim ve Bilim, 22(110), 7-11.

Baymur, F. (1994). Genel Psikoloji, İstanbul: İnkilâp Kitapevi, 169.

Cohen, J. (1988). Statistical power analysis for the behavioral sciences. New Jersey: Lawrence Erlbaum Associates Publishers

Cohen, L., Manion, L., \& Morrison, K. (2000). Research Methods in Education. 5th ed. London. New York: Routledge Falmer.

Cüceloğlu, D. (1996). İnsan ve Davranısı (6. Basım), İstanbul: Remzi Kitabevi.

Demirbaş, M., \& Yağbasan, R. (2004). Fen bilgisi öğretiminde, duyuşsal özelliklerin değerlendirilmesinin işlevi ve öğretim süreci içinde, öğretmen uygulamalarının analizi üzerine bir araşturma. Gą̧i Üniversitesi Kırşehir Eğitim Fakültesi, 5(2), 177-193. 
Güneş, I., \& Özsoy Güneş, İ. (2016). The Examination of the laboratory anxiety, state and trait anxiety of university students in high voltage laboratory. Journal of Human Sciences, 13(2), 3439-3445. doi:10.14687/jhs.v13i2.3922

Duman, G.K. (2008). İlköğretim 8. Simff Öğrencilerinin Durumluluk Sürekli Kayg̨ Düreyleri ile Sınav Kaygısı Düzeyleri ve Ana-Baba Tutumlan Arasidnaki Iliskkinin Incelenmesi. Yüksek Lisans Tezi, Dokuz Eylül Üniversitesi, Eğitim Bilimleri Enstitüsü, İzmir

Ergün, M. (1995). Bilimsel araștırmalarda bilgisayarla istatistik uygulamaları. Ankara, Ocak Yayınları.

Erökten, S. (2010). Fen bilgisi öğrencilerinde kimya laboratuvar uygulamalarının öğrenci endişeleri üzerine etkisinin değerlendirilmesi. Hacettepe Üniversitesi Eğitim Fakültesi Dergisi, 38, 107-114.

Geoffrey, A.M., \& Behets, D. (1999). Physical Education Teachers' Concerns towards Teaching. Teaching and Teacher Education, 15, 497-505.

Güneş, I., \& Özsoy-Güneş, Z. (2015). Developing High Voltage Laboratory Anxiety Scale; Validity And Reliability Study. Educational Researches and Publications Associations (ERPA), 4-7 June 2015

İnanç, B. (1997). Kayg1 ve Stres. Çukurova Üniversitesi Ĕ̈itim Fakültesi Dergisi, 2(16), 9-14.

Jones J.G. (1995). Competitive Anxiety in Sports Psychologys. Human Kinetics. London; pp 24-31.

Karasar, N. (2008). Bilimsel araştırma yöntemi: kavramlar, ilkeler, teknikler. Nobel yayın dağıtım Tic. Ltd. Şti.. Ankara.

Kalaycı, G. (2010). SPSS Uygulamah Çok Değģskenli İstatistik Teknikleri. (3. Baskı). Ankara: Asil Yayın Dağıtım.

Kurbaşlar, F. G., Özsoy-Güneş, Z., \& Deringöl, Y. (2008). Genel kimya laboratuvar uygulamalarında ilköğretim fen bilgisi ve matematik öğretmen adaylarının davranışları. Hasan Âli Yücel Ë̈̆tim Fakültesi Dergisi, 5(2).

Konter E. (1996). Sporda Stres ve Performans. Saray Yayınlar1, İzmir; ss 28-41.

Laukenmann, M., B1eicher, M., Fuß, S., Gläser-Zikuda, M., Mayring, P., Von Rhönec, C. (2003). An Investigation of the Influence of Emotional Factors on Learning in Physics Instruction. International Journal of Science Education, 25(4), 489-507.

Mintzes, J.J., Wandersee, J.H., \& Novak, J.D. (1998). Teacbing sciencefor understanding: A buman constructivist view. San Diego, Academic Press

Okur, M., \& Bahar, H.H. (2010). Learning Styles of Primary Education Prospective Mathematics Teachers; States of Trait-Anxiety and Academic Success. Procedia Social and Behavioral Sciences, 2, 3632-3637.

Öner N, Le Compte A. (1985). Durumluk-Sürekli Kaygı El Kitabı. B.Ü Yayınları, İstanbul.

Öner N, Le Compte A. (1998). Durumluk-Sürekli Kaygı El Kitabı. B.Ü Yayınlan, İstanbul.

Özyurt, G. (2013).Triple p olumlu anne-babahk eğitimi'nin anksiyete bozuklü̆u olan 8-12 yaş arası cocuklarda ve ebeveynlerinde anksiyete düzeyi ve ruh sağh̆ğ üzerine etkilerinin arastirnldiğ randomize kontrollü bir çalısma (Doctoral dissertation, Dokuz Eylül Üniversitesi Tıp Fakültesi).

Spielberger CD, Gorsuch RL, Lushene RE. (1970). Manual for the State-Trait Anxiety Inventory (selfevaluation questionnaire). Palo Alto: Consulting Psychologists Press.

Yeşilkayalı, E. (1996). İlkokul 4. smnf sosyal bilgiler dersinde problem çözme yönteminin ögrrencilerin okul başarlarn ve duyussal özellikleri üzerindeki etkisi. Yüksek Lisans Tezi, Dokuz Eylül Üniversitesi Sosyal Bilimler Enstitüsü: İzmir. 